
and Grassroots organisations in XXIst Century China

\title{
The Ram Union
}

Emergence of an International NGO Supported by the Party-state

\section{Emmanuel Jourda}

\section{Translator. Peter Brown}

\section{(2) OpenEdition}

\section{Journals}

Electronic version

URL: http://journals.openedition.org/chinaperspectives/9150

DOI: 10.4000/chinaperspectives.9150

ISSN: 1996-4617

Publisher

Centre d'étude français sur la Chine contemporaine

\section{Printed version}

Date of publication: 8 June 2019

Number of pages: $47-55$

ISSN: 2070-3449

\section{Electronic reference}

Emmanuel Jourda, «The Ram Union », China Perspectives [Online], 2019-2 | 2019, Online since 10 June 2020, connection on 23 December 2020. URL : http://journals.openedition.org/chinaperspectives/ 9150 ; DOI : https://doi.org/10.4000/chinaperspectives.9150 


\title{
The Ram Union
}

\author{
Emergence of an International NGO Supported by the Party-state
}

\author{
EMMANUEL IOURDA
}

\begin{abstract}
ABSRACT: The Ram Union is a non-profit social organisation established in 2003 in Zhejiang Province. Its transformation from a local entity into an international NG0 tells us about the methods implemented by the Chinese Communist Party (CCP) to accompany the development of popular associations or minjian, which appear to be external to the Party but which in fact are fully sponsored by it. Studying such organisations is a complex matter, as they appear to act in a benevolent and apolitical manner, while being completely integrated within the political and social apparatus of the Party-state (Youth League, volunteers, United Front, ministry of Civil Affairs, etc.). The historical trajectory of the Ram Union thus gives us insight into the CCP's overlooked strategy of hybridisation, involving mass organisations that came out of the revolutionary period and charitable groups embodying modern Chinese society. This strategy is designed to occupy the social arena and forestall the emergence of an autonomous Chinese civil society in the People's Republic of China (PRC) or among the Chinese diaspora overseas.
\end{abstract}

KEYWORDS: Minjian, structure, social organisation, non-government organisation, volunteers, Communist Youth League, United Front, CPPCC, Minmeng, overseas Chinese.

\section{Introduction}

T he Ram Union has increased its visibility over the past few years under the umbrella category of Chinese "social organisations" (shehui tuanti 社会团体) (1) within the "sphere of the people" (minjian 民间). This ambiguous expression refers to groups that act in a more or less independent way with regard to the Party-state, among the lower echelons of society. The difficulty concerns their assimilation or not to Western-style NGOs (Saich 2000; Billioud and Thoraval 2014), at a time when the Chinese Communist Party (CCP) is trying its utmost to "include and contain" (baorong 包容) (Qi 2011) gatherings and rallies of all kinds, to avoid the development of a fully functioning civil society in the People's Republic.

The Ram Union was formed in 2003 in Hangzhou, when Xi Jinping 习近平 was secretary of the CCP in Zhejiang Province, involving volunteers with a humanitarian vision. It specialised in offering relief assistance to populations affected by natural disasters. It really took off with the 2008 earthquake in Sichuan. Since then, the field of action of this socially recognised body has been extended in terms of its missions, taking in social and cultural activities, and its geographical range, both within the People's Republic of China (PRC) and abroad.

The Ram Union, which calls itself "independent" (duli 独立) from the authorities, has become the expression of the dynamism and altruism of Chinese society. The development of this humanitarian social body, which claims the status of an NGO in the Western sense of the term, has been the subject, however, of constant scrutiny by the Communist Party. Its evolution is therefore not the mere reflection of a particular period that has seen the spontaneous rise of Chinese society in the public arena serving the public interest. It illustrates the way in which the CCP structures, "attracts" (xina 吸纳) (Yao and Ren 2013) and absorbs new social manifestations, in order to encourage the emergence of a select local elite. The Rams take part, in their fields of competence, in the collective effort to monopolise the social sphere and embody a nation that is conforming to the expectations of the Party, under the cover of a disinterested apolitical stance.
Two intermediary bodies of the Party-state, serving as an interface for it with society, have accompanied the emergence of the present form of this entity. These are the Communist Youth League, which structures the movements of Chinese volunteers in the sphere of social and humanitarian action, and the network of the United Front, ${ }^{(2)}$ which is active at the urban neighbourhood level, in order to strengthen social stability and local politics. This dual patronage has turned the Ram Union into a quasi-diplomatic showcase and an exportable model within the Chinese diaspora. "Scrupulously respecting" (yange zunshou 严格遵守) the laws and regulations of the PRC, (3) it presents itself as being at the service of a "harmonious society" (hexie shehui 和谐社会).A supposed model of a people's initiative working for the common good and spreading Chinese cultural and sporting values, it can also be, when needed, the interlocutor of institutional actors, in order to contain social movements from which autonomous political demands could arise.

As the Ram Union has not been studied before, there is scant information on the subject. What little is available comes either from its own website ${ }^{(4)}$ or certain online articles. (5) In this article, I will compensate for the lack of information needed to characterise with any precision the origin, changes, and institutional functioning of this body by contextualising what infor-

1. The translation of shehui tuanti as social organisations distinguishes them from non-governmental organisations, which by definition are generally independent of the political authorities. In this, we follow the reasoning of Tony Saich (2000).

2. The United Front (Tongyi zhanxian 统一战线) is a political concept imported from the USSR in the 1920s that enables the Communists to reach out to all social and political groups that were non-communist. Initially conceived to prepare for the revolution, since 1978 it has been used to help develop the nationalisation of the CCP. It has become a tool for integrating all facets of society. The work of the United Front is devolved, in particular, to so-called United Front institutions dedicated to that purpose (see below)

3. “公羊会简介” (Gongyanghui jianjie, A succinct presentation of the Ram Union), http://en.ramunion.org/facts (accessed on 11 November 2017)

4. See http://www.ramunion.org/.

5. This literature is either directly within the province of the Union or confined to a range of articles in the local press that are quite factual in nature and without any perspective, often close to a copy-and-paste style, whose rationale is to promote its non-intellectualised and supposedly apolitical action. Overall, this offers little room for debate about its role or for any soul-searching about its activism. 
mation is available. To this end, I adopt a structural approach (Schurmann 1968), underpinned by recent research on the Youth League and volunteering, as well as by writings on the work of the United Front. My aim is to situate the Ram Union within a broader reflection underway on the in-between organisations promoted by the CCP, which should lead to a reappraisal of the notion of minjian. In this perspective, the first part of the article will provide an overview of this social organisation, which claims to be an NGO with an international vocation, in order to define its positioning as an intermediary structure between the CCP and Chinese society in the name of the public interest. (6) Secondly, the symbolic and structural cartography thus presented will offer an original analytical grid for deciphering the process of crisis resolution that put an end to the riots that appeared within the Chinese diaspora in Paris in the spring of 2017.

\section{A local benevolent structure with a global mission}

At the outset, the "Ram Union" (Gongyanghui 公羊会), ${ }^{(7)}$ set up in 2003, was an outgrowth of a local entity, "the association of outdoor activities in the city of Hangzhou" (Hangzhoushi huwai yundong xiehui 杭州市户外运 动协会). From this initial root, and in ways still unknown, it became part of a municipal structure in the service of the local community, whose activities ranged from sport to providing help to individuals in need. ${ }^{(8)}$

To begin with, its name provides little enlightenment as to its objective or stance. However, in deconstructing it and its slogan, the organisation appears as a kind of minjian organisation acting in the public interest in tandem with the regime.

\section{An animal label at the service of public affairs}

Its name is the product of a play on words around the Chinese expression gongyang 公羊, meaning "ram." This is comprised of yang 羊, a generic term for ovines, and gong 公, which is the crux of the pun. When applied to animals, gong represents the male. More generally, gong has multiple meanings. It presents the idea of the universal, in particular the ability to take care of everyone and everything, impartially and inclusively. It therefore engages the notion of the common good, of public interest and state affairs, enhanced by a certain social morality.

The Ram Union therefore presents itself ${ }^{(9)}$ as the association of ovines operating at the service of the "public interest" (gongyi 公益). In other words, as a body made up of "good and kind" (xing shanliang, wenhe 性善良, 温和) individuals acting as volunteers, which is out in the open working for the community. This social group is not a random herd lacking order; rather, its members describe themselves as "soldiers/scholars in the service of public interest" (yishi 益士), and represent themselves therefore in marching order ready to accomplish a noble task.

There is no precise reference substantiating the influences underpinning this play on words. ${ }^{(10)}$ However, the analogy with the Commentary of Congyang (Gongyang zhuan 公羊传), one of the three historical commentaries of The Spring and Autumn Annals (Chunqiu 春秋), (11) cannot be excluded. The Ram Union is contemporaneous with the revival of Confucianism in the PRC. The year of its creation was also that of the publication in China of a sweeping work entitled Political Confucianism (Zhengzhi Ruxue 政治儒学) (Jiang 2003), which received a great deal of coverage. The Commentary of Gongyang is seen as a political treatise for an ideal dynasty. It is a source of teaching applicable in a very concrete way to contemporary society, in terms of respect for public order embodied by a just power. This congruence, in terms of time and name, allows us to include the Ram Union in the pragmatic and realist strand of this thinking. The action of this organisation, in the service of the common good, may therefore be seen as falling within a political, social, and moral Confucianist approach, in the service of good governance (Billioud and Thoraval 2009). The reference to the ram would thus be no more than a metaphor, symbolised by the logo of the organisation that represents a stylised ram's head. Its slogan further backs up this hypothesis.

\section{A pastoral motto in the service of power}

The motto of the Ram Union is "Choose the watercourse to live by, seek out pastures to sow your seeds" (ze shui wei sheng, zhu cao er ju 擇水為生, 逐草而居). ${ }^{(12)}$ The second part of this saying is virtually derived from the expression "move in search of water and grazing land to settle in" (zhu shuicao er ju 逐水草而居), which refers to the nomadic lifestyle of the steppe peoples. If superficially applied to the Rams, it would bring out their vitality and their forthrightness with respect to the vast open spaces. Their nationalisation and internationalisation (see below) allow for a more overall political reading, ${ }^{(13)}$ namely, that of the underlying expression of an expansionism that is in tune with the Party.

The first two characters of the first part (擇水) and the last two of the second part (而居) comprise the beginning of the classical expression "choose the watercourse to settle by, choose the tree to shelter under" (ze shui er ju, ze mu er qi 择水而居, 择木而栖). This may be extended as follows: "The good bird chooses the tree in which to make its nest, the wise servant of the state supports and serves with humility" (liangniao ze mu er qi, xianchen zhu er shi 良鸟择木而栖, 贤臣拄而侍). Their name and motto suggest that the good men of the Gongyanghui show their devotion to the just Mandarin ruling the country. Based on this analysis, the Ram Union can be defined as a minjian-type organisation in the service of the general interest embodied by the CCP, which in recent years has been creating a neo-Confucian image for itself.

6. Further research, beyond the scope of this article, is required to grasp this entity in its entirety. The career paths and guanxi of its founding members (filiation and sponsorship); its sources of income, direct and indirect (gifts, subsidies, other means of support); the tree view of its website, etc.

7. See the organisation's website: http://www.ramunion.org/

8. It has not been possible for me to explore more fully these questions associated with the initial form of this "municipal" structure. Is it a minjian structure that has been co-opted or an underorganisation of the Youth League? This positioning implies an institutional aspect that is recognised or at least integrated, without it being possible at present to determine its official level or original orthodoxy; nor can we know the relevance of these categories applied to an entity of limited scope that is devoted to activities that attracted little attention at the time.

9. See the presentation on the organisation's website: http://www.ramunion.org (accessed on 11 November 2017)

10. The name gongyang 公羊 can make one think of the near homophone 供养, which means "providing for someone's needs."

11. This text was supposedly transcribed by Gongyang Gao 公羊高, called Gongyang 公羊, a disciple of Bu Shang 卜商, himself a disciple of Confucius.

12. “公羊队” (Gongyangdui, The Interventionist Ram Unit), 21 October 2014, Zhejiang wenming wang 浙江文明网, http://www.zjwmw.com/07zjwm/system/2014/10/21/020315104.shtml (accessed on 11 November 2017).

13. The creation of the Ram Union was also contemporaneous with the publication of the novel by Jiang Rong 姜戎, Wolf Totem (Lang tuteng 狼图腾) which, under the guise of a pastoral story in Inner Mongolia during the Cultural Revolution, is a political reflection on China. 


\section{An orthodox multi-purpose structure of volunteers}

Through its charitable work, the Ram Union depends on state and Party structures that mobilise and structure the "volunteers" (zhiyuanzhe 志愿者). ${ }^{(14)}$ It is placed under the ideological care of the services in charge of these questions within the Communist Youth League (Gongqingtuan 共 青团). By dint of their field of action, the Rams are administratively attached to the division of the rescue operations for the victims of natural disasters, within the ministry of Civil Affairs (Minzhengbu jiuzaisi 民政部救灾司). Falling under this dual system, both political and administrative, they are duly "approved" (hezhun 核准) by the Party-state apparatus.

The evolving nature of the Ram Union fits in with the chronology of the Youth League volunteers. In 2003, the League promoted the strengthening of assistance to the disenfranchised rural regions (Palmer and Ning forthcoming), in particular via the Great Western Development Strategy (Xibu jihua 西部计 划).The Ram Union was formally set up the same year in order to provide relief in areas where a natural disaster had occurred, which often happened to be in the western part of the country. However, it did not yet have any real visibility. In 2006-2007, volunteering as a ground-up, unstructured, and often ephemeral initiative, it really took off. ${ }^{(15)}$ In order to support it, the Party drew up a list of the "eight honours" that advocated the involvement of individuals in the disinterested service of national development. ${ }^{(16)}$ In May 2008, the Sichuan earthquake gave rise to an enthusiasm for helping others and for human solidarity. The Ram Union stood out within the context of this humanitarian dynamic. In July, the CCP mobilised volunteers for the Beijing Olympics. The Party then got involved in organising this nebulous entity, in order to fill the void between mass movements orchestrated on a large scale and informal initiatives undertaken locally. The year 2008 was then considered to be volunteering's "Year 1," or at least that of its reconstitution by the Party (ibid.).

Beginning in March 2009, the Bureau of Civil Affairs in Hangzhou approved the transformation of the Congyanghui into a "public interest foundation of the Rams of Hangzhou" (Hangzhoushi Gongyanghui gongyi jijinhui 杭州 市公羊会公益基金会), with the "Ram intervention unit" (gongyangdui 公羊 队) (17) at its core. In 2012, the controlling group for spiritual culture of the Politburo of the CCP, in order to perfect the ideological structuring of the volunteers, put the final gloss on the transformation of Lei Feng 雷锋, a former figure of revolutionary propaganda, into the patron saint of volunteering (ibid.). Accordingly, the Ram Union celebrated his exemplary nature. ${ }^{(18)}$ In 2015, the volunteer programme was directed towards the west in the name of the Motherland (ibid.). From 2013, Ram teams were sent into disadvantaged western regions, Tibet, Xinjiang, and Gansu, to help those most in need and support the construction of schools and clinics. ${ }^{(19)}$

\section{Broadening its field of action}

Since 2008, volunteering has been seen as a display of Chinese civility, embodying a magnified representation of the model citizen (Chong 2011), and apolitical. All spheres of volunteering have become vectors of this engagement: crisis relief, poverty alleviation, environmental protection, charity work, etc. All of this fits into a strategy of "developing a citizen society" (gongmin shehui de chengzhang 公民社会的成长) devised to avoid the emergence of an alternative politics within this social outpouring. For the Party, which has always mistrusted unsupervised popular initiatives, the difficulty lies in how to apprehend this "volunteering" spirit (zhiyuanxing
志愿性), and more generally any "non-state activity" (fei zhengfuxing 非政府性) (Wang 2012). One of the ways adopted consists of favouring certain minjian structures so that they invest in these fields of activity, in order for their presence to prevent the emergence of rival groups or to snuff out pre-existing ones. The more activities the chosen social organisations have, the more they can occupy the social sphere. Working on the ground, in "neighbourhood streets and communities" (jiedao shequ 街道社区) (Zhong 2001; Audin 2013), becomes a major focus.

Little by little, the Rams began to engage in cultural and sporting activities as well as in "neighbourhood" actions (jiceng 基层), notably in the awarding of scholarships to young under-privileged students. In 2009, a Dragon Boat team was formed (longzhoudui 龙舟队) (20) when the Duanwujie Festival 端午节, the highlight of which is a race for this kind of watercraft, was recognised by UNESCO as intangible cultural heritage. (21) In September 2014, the Ram Public Interest University was launched (Gongyanghui gongyi daxue 公羊会公益大学) in order to offer social and cultural activities to the physically and mentally impaired and to the elderly.

All this leads one to think that the citizen volunteering of the Ram Union is working for the development of the "democratic neighbourhood consultation" (jiceng xieshang minzhu 基层协商民主) (Chen 2017) advocated by the Party, with the aim of detecting and structuring developing social dynamism to feed into the hegemonic representativeness of the CCP. This work was devolved in particular to the network of the United Front (Jourda 2012). The link between volunteering and the work of the United Front is even easier as the Youth League contributes to it through the Chinese Youth Federation (Zhonghua qinglian lianhehui 中华青年联合会) (Doyon 2017). Since the founder of the Ram Union is a leading cadre of the Federation (see below), his "personal" action supports this view of institutional synergy.

\section{A United Front relay organisation}

The United Front, which detects and channels the emergence of minjian, has several layers. The United Front Work Department (UFWD) of the Central Committee of the CCP (Zhonggong zhongyang tongyi zhanxian gongzuo bumen 中 共中央统一战线工作部门 - Tongzhanbu 统战部) is the executive. The Chinese

14. Ever since the time of Yan'an and right up until the end of the Cultural Revolution, volunteers formed part of the civil forces that could be mobilised for the political battles of the Party. The concept of volunteers then fell into disuse, only to be reactivated in the 1990s, albeit in a context of depoliticised social engagement.

15. Between 2006 and 2007, the number of organisations tripled to reach 270,000 (Palmer and Ning forthcoming).

16. Eight Honours and Disgraces (Ba rong ba chi 八荣八耻): It is glorious to love the Fatherland, to serve the people, the promote science, to be diligent and hardworking, to be united and show solidarity, to be honest and worthy of trust, to respect rules and laws, to struggle and endure (Billioud 2007).

17. The status of foundation is difficult to obtain in China. This point denotes a high level of integration within the Party-state apparatus. However, due to a lack of information I have not been able to define further how this change came about in practice.

18. “学雷锋, 促公益, 上海公羊会在行动!” (Xue Lei Feng, cu gongyi, Shanghai Congyanghui zai xingsong! Studying Lei Feng, promoting the public interest, the Ram Union of Shanghai at work!), 29 March 2018, http://www.ramunion.org/news.detail/id-277 (accessed on 28 May 2018).

19. See “公羊会暖冬行动” (Gongyanghui nuandong xingdong, The actions of the Ram Union for a warm winter), http://www.ramunion.org/news.detail/id-51 (accessed on 9 December 2017).

20. “2016 第四届公羊会端午龙舟国际邀请赛” (2016 di si jie Gongyanghui duanwujie longzhou guoji yaoqingsai, 2016: The fourth international invitation of the Ram Union for the Dragon Boat Race Festival), 9 June 2016, http://www.ramunion.org/news.detail/id-25 (accessed on 10 October 2017).

21. Zhu Shanshan, "Dragon Boat Festival named a UNESCO intangible cultural heritage," Global Times, 2 October 2009, http://www.globaltimes.cn/content/474345.shtml (accessed on 7 February 2019). 
People's Political Consultative Conference (CPPCC) (Zhongguo renmin zhengzh xieshang huiyi 中国人民政治协商会议 - Zhengxie 政协) is the deliberative body without any legislative power housing the eight democratic parties (ba ge minzhu dang 八个民主党).They provide the Chinese regime with a connotation of pluralism. The whole system, made up of many geographical subdivisions, is responsible for detecting social movements, channelling them, and accompanying their political rise by turning them into a representative model of the local elite.

Xi Jinping himself called for an intensification of the action of the United Front apparatus from the very outset of his mandate at the helm of the PRC. This dynamic is quite evident in the province of Zhejiang, which serves as a political and social laboratory, no doubt due to the fact that $\mathrm{Xi}$ Jinping was Party Secretary there from 2002 to 2007.

In February 2003, the year of the Ram Union's creation in Hangzhou, Hu Jintao 胡锦涛 launched the slogan "Three for the people" (san ge wei min 三个为民), to stress the fact that the CCP does not cut itself off from the Chinese people. This was in order to compensate for the introduction of the very elitist "Three representations" (san ge daibiao 三个代表) (Holbig 2009). Henceforth, the democratic parties were encouraged by the United Front Work Department (UFWD) to lend greater support to this national cause, particularly around the subjects of environmental protection (huanjing baohu 环境保护), vulnerable groups (ruoshi qunti 弱势群体), and social stability (shehui wending 社会稳定) (Zhu 2009). In order to build the "social harmony" desired by Hu Jintao, the city of Hangzhou developed the concept of "promoting the means of existence through democracy" (yi minzhu cu minsheng 以民主促民生) (Yang 2015). Quality of life, in particular thanks to local initiatives, thus became a political issue.

The coupling of "the people's means of existence - democracy" (minsheng - minzhu 民生 - 民主) (Zhu and Yu 2015) seems to be the frame of reference for the work on the ground carried out by the Ram Union. The extension of its field of action (helping people in need, assisting students, neighbourhood life, protecting the environment, spreading Chinese culture, etc.), following the rise of Xi Jinping, supported local wellbeing and served as a potential vector for mobilising engagement, both of the volunteers and their interlocutors. Even though the Ram Union does not directly take part in the process of political consultation, its minjian action comes perfectly within the first stage of this work by the United Front. The profile of its cadres seems to suggest that the second part is implied.

Several of its leaders are branch members of two Zhejiang democratic parties: the Chinese Democratic League (Zhongguo minzhu tongmeng 中国民 主同盟), known as Minmeng (民盟), (22) and the China National Democratic Construction Association (Zhongguo minzhu jianguohui 中国民主建国会), called Minjian (民建). ${ }^{(23)}$ As entrepreneurs, they often hold positions in Chambers of Commerce or guilds, or even sit on local or national decision-making bodies of the CPPCC or the National People's Congress. As such, they are a link in the United Front chain. The Ram Union therefore appears to be in phase with all the Party's expectations in terms of volunteering and United Front actions on the ground in neighbourhoods. The profile of the head of the Rams himself appears to be the embodiment of this seamless web.

\section{A founding president at the juncture of structural issues of importance}

The man behind the Ram Union, He Jun 何军, born in 1970 into a family of Party cadres (ganbu jiating 干部家庭), (24) personifies the double supervi- sory role of the set-up. He is a perfect example of the new generation of philanthropic entrepreneurs. He received an education in science abroad, is a member of various local or regional bodies of the United Front and the Youth League, namely the Minmeng, the Youth Federation, the National People's Congress, the Federation of Overseas Chinese who have returned to China to live, Chambers of Commerce, volunteering organisations, and bodies looking after charity groups. He embodies the combination of individual success and altruism, for which he has picked up a suite of honours and merit awards bestowed by the municipality of Hangzhou, the UFWD, the CPPCC, the Red Cross, etc. He is one of Hangzhou's "ten finest people" (shi jia meili xingfu renwu 十佳美丽幸福人物), "a civilian hero and model of morality" (pingmin yingxiong daode mofan 平民英雄道德模范), who is also part of the "ten overseas heroes" (qiaojie shi jie 侨界十杰) of Zhejiang. He is portrayed as a nationwide example for young people (quanguo xiangshang xiang shanhao qingnian 全国向上向善好青年). ${ }^{(25)}$

This institutional recognition has enabled him to have official meetings with state and Party leaders who represent the dual supervisory function of the Ram Union: Li Yuanchao 李源潮, Vice-President of the State Council of the PRC; Chen Xiaoguang 陈晓光, Vice-President of the CPPCC, Lin Jun 林军, President of the Federation of Overseas Chinese; Wang Huizhong 王 辉忠, Vice-President of the standing committee of the Zhejiang Provincial Party Committee; He Junke 贺军科, Secretary-General of the Youth League; and Dou Yupei 窦玉沛, Vice-Minister of Civil Affairs. (26)

This orthodoxy is paying off. In August 2016, the ministry of Civil Affairs announced publicly that the Ram Union had the right to become a national body of public interest (quanguoxing gongyi zuzhi 全国性公益组织) and lent it its "support" (zhichi 支持) for the Union's international outreach (zou xiang guoji 走向国际) (27) in order for it to become an international NGO (guoji NGO zuzhi 国际NGO组织). ${ }^{(28)}$ Within China itself, this recognition has enabled it to open branches at the municipal level in Shanghai, Lishui (Zhejiang), and Beijing, as well as at the provincial level in Xinjiang, Sichuan, Zhejiang, and Ningxia. It is, however, its overseas development that most determines the political issues that accompany this makeover and the means of its "becoming an NGO."

\section{An international minjian action}

The international profiling of the Ram Union, which was worked out under $\mathrm{Hu}$ Jintao, is being fully put into practice under Xi Jinping. It is enabling this social organisation to present itself as the "World Ram Union" (Quanqiu

22. Established in 1941, this was the most important of all the democratic parties, bringing together mainly intellectuals, teachers, and professionals. The Minmeng was particularly prominent through its help to the poor regions, especially in the great west, and in other topical national subjects.

23. Created in Chonqing in 1945, its members are typically business leaders, industry executives, engineers, and economists. As for the Minjian, its action lies principally in the economic sphere.

24. “何军 (公羊会创始人)" (He Jun (Gongyanghui chuangshiren), He Jun (the founder of the Ram Union)), Baidu 百度, https://baike.baidu.com/item/\%E4\%BD\%95\%E5\%86\%9B/17013928 (accessed on 7 December 2017).

25. “何军” (He Jun), http://en.ramunion.org/motto (accessed on 7 December 2017)

26. “全球公羊会” (Quanqiu Gongyanghui, World Ram Union), Baidu 百度, https://baike.baidu.com/ item/\%E5\%85\%A8\%E7\%90\%83\%E5\%85\%AC\%E7\%BE\%8A\%E4\%BC\%9A (accessed on 15 April 2018).

27. With regard to the difficulties already mentioned in becoming a foundation and obtaining the right to expand into other regions of China and abroad, it is likely that the ministry granted it this status in a very concerted way, albeit following procedures that are beyond my knowledge.

28. “中国民政部副部长顾朝㬢莅临公羊会视察” (Zhongguo minzhengbu fubuzhang Gu Chaoyi weilin Gongyanghui shicha, Gu Chaoyi, Vice-Minister of the Chinese ministry of Civil Affairs, comes to inspect the Gongyanghui), 17 August 2016, http://en.ramunion.org/news.detail/id-94 (accessed on 17 April 2018) 
Gongyanghui 全球公羊会). ${ }^{(29)}$ This transformation fits in with the international revolutionary legacy of the Youth League (30) and the United Front (Armstrong 1997). Henceforth, the strategy is to present China in a favourable light, to tackle irredentist Chinese questions, and set forth to the Chinese diaspora the neighbourhood action policy that is being implemented within the PRC. This form of parallel diplomacy has all the hallmarks of a United Front strategy.

\section{High-level social visibility}

In 2014, He Jun was a member of the Chinese delegation invited by the France-China Foundation (31) to meet movers and shakers in France. Under the auspices of the Vice-President of the State Council, Li Yuanchao, this delegation was mainly composed of members of the ministry of Foreign Affairs, politicians, scientists, businessmen, and financiers, as well as a senior executive of the Party School and an official of the CPPCC of Hangzhou. He Jun was included in it as President of the Ram Union and top-ranking official of the Youth Federation of Zhejiang. In the presentation brochure, the Union is described in English as a not-for-profit non-governmental relief organisation. ${ }^{(32)}$ Beginning in 2014, that is, two years before the ministry of Civil Affairs granted it international status, the Ram Union was already the very organisational model of a minjian, exemplary enough to be given visibility outside of China. Its political recognition by the Party thus preceded its administrative makeover.

\section{A humanitarian window}

The Youth League has been sending volunteers abroad ever since 2002, with the momentum being stepped up since 2009. Hundreds of volunteers have gone to Myanmar, Ethiopia, Guyana, etc., for periods ranging from six months to a year, to teach Chinese, health and hygiene, IT, etc. (Palmer and Ning forthcoming). The creation of the Ram Union and its subsequent takeoff also confirm this timeline. At the same time as it became a public interest Foundation, its rescue and relief wing was going into earthquake-affected areas, in particular Nepal, Pakistan, and Ecuador. Its coverage now also includes Europe. In August 2016, it went to Amatrice in Italy, a place that had been struck by an earthquake. ${ }^{(33)}$

Its most notable action in terms of United Front remains the Taiwan earthquake in February of the same year. Sending a team there was made possible thanks to a Sino-Taiwanese couple who are members of the Ram Union in Hangzhou. This move seems to have been their own minjian initiative, without any official accreditation, under the guise of a tourist visa. This action forms part of a strong Chinese irredentist position, however. To this end, the CCP is creating a number of entities that promote so-called United Front contacts between the populations on either side of the Taiwan Strait, in order to fight against the development of an island-based civil society supporting Taiwan independence.

The Ram Union's projections in this island do not seem to have met with much success. Without any coordination with the services in charge of rescue operations, their role was not mentioned by the local press and their presence was puzzling for the island's authorities. ${ }^{(34)}$ Their patriotic image might have been enhanced as a result, (35) but the feedback given by the volunteers themselves proves to be less conclusive. These projections into affected areas, both in China and overseas, reveal the ongoing difficulties encountered by the volunteers. China Youth Daily (Zhongguo qingnian bao 中国青年报), an official organ of the Youth League, ${ }^{(36)}$ reported in one of its articles after their Taiwan sojourn that volunteers in China had trouble being accepted by the authorities in the affected areas where they operated and receiving recognition by the specialist services. As a result, they had difficulty gaining technical know-how. In Taiwan, however, the Ram Union noticed the inclusion of island-based volunteers in the local operation. The cooperation among professionals and NGOs would therefore seem to be a source of potential inspiration for the PRC. (37)

The extension of the Ram Union overseas, as a sporting and cultural NGO, represents an expansion axis that is easier to implement and guarantees a higher visibility within the United Front network. This move notably involves the organisation of and participation in Dragon Boat races.

\section{A new relay structure within the diaspora}

In the early years 2010, the Party-state of Zhejiang turned He Jun into a major figure among the representatives of Overseas Chinese through his own experience abroad. The internationalisation of the Ram Union in 2016 enabled He to open up branches in England, Italy, France, the Netherlands, Germany, and Austria, but it was the French entity that received the most coverage in the Chinese media.

In May 2016, the Ram Union made much of its participation in a Dragon Boat race in Dallas, Texas. ${ }^{(38)}$ In June, that is, two months prior to the official announcement in China of the internationalisation of the social organisation, preparations took place to set up a Ram branch in France. ${ }^{(39)}$ In July, the General Association of the Ram Union of France (Gongyanghui Faguo zonghui 公羊会法国总会) was launched in the presence of He Jun, ${ }^{(40)}$ as well as the Chinese Embassy and representatives of the various diaspora as-

29. “全球公羊会" (Quanqiu Gongyanghui, World Ram Union), Baidu 百度, https://baike.baidu.com/ item/\%E5\%85\%A8\%E7\%90\%83\%E5\%85\%AC\%E7\%BE\%8A\%E4\%BC\%9A (accessed on 15 April 2018).

30. In particular that of the Korean War

31. Set up in 2012, the France-China Foundation promotes exchanges between high-level French and Chinese figures. Its "Young Leaders" program puts forward those likely to play an important role in their country, either internationally or in France-China relations, as well as institutionally, politically, economically, and socially.

32. See the Foundation's own website: http://francechinafoundation.org/wp-content/uploads/ 2014/05/List-of-Young-Leaders-2014.pdf (accessed on 18 October 2017).

33. "China rescue team rushes to Italy for earthquake relief," Xinhua, 26 August 2016, http://en.people.cn/n3/2016/0826/c90777-9106203.html (accessed on 15 November 2017).

34. Zheng Zhonglan 郑仲岗, “台湾海基会: 大陆'公羊会'赴台救灾'目的不合'” (Taiwan Haijihui: Dalu "Gongyanghui" fu Tai jiuzai "mudi bu he," According to the Straits Exchange Foundation, the avowed motive of the "Mainland Gongyanghui" going to Taiwan "does not add up"), BBC, 16 February 2016, http://www.bbc.com/zhongwen/simp/china/2016/02/160209_taiwan_earthquake _china_rescue_team (accessed on 15 November 2017).

35. “科地公羊队小年夜出征, 援助台湾同胞!” (Kedi Congyangdui xiaonianye chuzheng, yuanzhu Taiwan tongbao! The Ram team in Kedi left in the New Year to help their Taiwanese compatriots!), 6 February 2016, http://www.ramunion.org/news.detail/id-146 (accessed on 22 September 2017).

36. Zhang Zheng 章正, “公羊会的成长烦恼” (Gongyanghui de chengzhang fannao, The growing concerns of the Gongyanghui), China Youth Daily 中国青年报, 2 March 2016, http://zqb.cyol.com/ html/2016-03/02/nw.D110000zgqnb_20160302_3-07.htm (accessed on 22 September 2017).

37. Zheng Zhonglan 郑仲岗, art. cit.

38. “公羊会竞速龙舟队在达拉斯龙舟大赛获得A组冠军” (Congyanghui jingshu longzhoudui zai Dalasi longzhou da sa huode A zu guanjun, The Dragon Boat of the Ram Union came first in A Group in the Dallas Dragon Boat race), 15 May 2016, http://www.ramunion.org/news.detail/id865 (accessed on 22 September 2017).

39. “边海峰介绍公羊会” (Bian Haifeng jieshao Gongyanghui, Bian Haifeng presents the Ram Union of France), Tengxun shiping 腾讯视频, 24 January 2017, https://v.q9.com/x/page/m0369 af3hd7.html (accessed on 13 January 2018).

40. “公羊会法国总会成立一开启华界慈善公益新篇章” (Gongyanghui Faguo zonghui chengli kaiqi huajie cishan gongyi xinpianzhang, Creation of the Ram Union of France - Opening of a new branch of this charitable organisation of community public interest for the community), 1 July 2016, http://www.ramunion.org/news.detail/id-99 (accessed on 24 February 2018). 
sociations. The event was covered by the Chinese press. ${ }^{(41)}$ The new structure was set up on the Hangzhou model. The members are businessmen who wish to work for the public benefit. They are already part of various community associations serving in France as guilds/chambers of commerce. The public announcement of the ministry of Civil Affairs of the PRC did not occur until August. This means that it validated a decision that had already been taken and put into practice.

In January 2017, Franck Bian Haifeng 边海峰, the Secretary-General of the Ram Union of France, appeared in a video on the internet to present the objective of this new community organisation. ${ }^{(42)}$ In it, he mentions that it was set up in "accounting" (baobei 报备) to the Chinese Consulate and that it lists itself as a not-for-profit association of the type allowed for under the French law of 1901, acting in the public interest and for the betterment of cultural relations between France and China. He adds that he hopes to work in tandem with the older local associations and be "integrated" (rongru 融入) with them in order to "build together a harmonious diasporic society" (gong jian hexie qiaoshe 共建和谐侨社) in a patriotic perspective. The association then celebrated the Chinese New Year in the presence of the Embassy. ${ }^{(43)}$ The diplomatic representation of the Party-state therefore appears as the overseer of this minjian griffin at the heart of social representations of the diaspora.

In February, a declaration was lodged at the Préfecture of the Yvelines Département near Paris in the name of Ramunion France, and registration was obtained in March. Its stated aim is to provide social assistance to the public and foster cultural exchanges between France and China. ${ }^{(44)}$ Classified under the category "recreational clubs, relations (exchange networks)" (45) or "recreation and social life," (46) the association thus benefited from six months of diplomatic recognition by China and organised festivities in the diaspora without actually having had any legal standing in France. The pace of development of the Rams therefore seems to have been a function of the Chinese state apparatus before being accredited by the French authorities. In China, as in France, the process is as follows: the Party-state, directly or through middle parties, endorses the development of the Ram Union, then the administrative bodies, either Chinese or foreign, sanction its effectiveness. The Ram Union is constructing its developing NGO stance through this internationalisation. In order to do so, it refers to the legislation in countries where it is set up and which then assimilates it to similar bodies in the local civil society. ${ }^{(47)}$ It is on this basis of being considered as an association that it can serendipitously come out as a body serving as an intermediary between institutions and society.

In Paris on 26 March, Liu Shaoyao 刘少尧, a Chinese national, died during a police visit to his home. This drama quickly gave vent to feelings of anger within the Chinese diaspora, an expression both by citizens as individuals and by a whole community. This reaction was a mix of several distinct elements. On the one hand, it reflects calls for recognition by second and third generation migrants mainly from the Wenzhou area (Zhejiang), in the context of generational emancipation. It can also be seen as the expression of this diaspora experiencing gentrification and seeking greater recognition in French society. Thirdly, there is an exasperation faced with a feeling of insecurity as a result of attacks on Asians in the Parisian neighbourhoods of Belleville and Aubervilliers. ${ }^{(48)}$

The Chinese Embassy, sometimes accused of appearing to be relatively indifferent to the difficulties of the diaspora, reacted promptly to the event, ${ }^{(49)}$ to the point of causing a diplomatic incident. ${ }^{(50)}$ Around the street demonstrations there appeared individuals who were looking to clash with the police as if to provoke a riot. (51) This Parisian community's expression of mourning and anger then turned into a politicised international media beat-up playing off anti-French racism in the PRC. ${ }^{(52)}$

As the situation became worse, the Beijing authorities renewed their support to the social movement, which was without particular shape given its plural nature, via community-based associations as a way of containing it. This move had the advantage of providing interlocutors who had accreditation at the Préfecture of Police in Paris. Among them was Franck Bian Haifeng of the freshly created Ramunion France, ${ }^{(53)}$ whereas the others were often members of long-established organisations in the history of Chinese immigration (associations of fellow provincials, youth, the lawyers' community, guilds, etc.). After having existed legally for a month, the French Ram Union was thus elevated to the rank of a community association that was representative enough to play a role in this crisis.

Another United Front organisation was also called upon for action. This was the French Association for the Promotion of the Peaceful Reunification of China (Faguo Zhongguo heping tongyi cujinhui 法国中国和平统一促进 会), under the helm of Wang Jiaqing 王加清. This is an offshoot of a Beijing

41. “公羊会法国总会成立开启华界慈善公益新篇章” ("Congyanghui” Faguo zonghui chengli kaiqi huajie cishan gongyi xinpianzhang, Creation of the "Congyanghui" of France, Opening of a new branch of this charitable organisation of community public interest), Ouzhou shibao 欧洲时报, 5 July 2016, http://www.oushinet.com/aj/ajnews/20160705/235081.html (accessed on 24 February 2018).

42. “边海峰介绍公羊会," art. cit.

43. “倡公益, 迎新春'法国公羊会举行新春晚会” (“Chang gongyi, ying xinchun” Faguo Gongyanghui juxing xinchun wanhui, "Promoting public interest, welcoming in the new year," the Ram Union of France organises the New Year's celebrations), Ouzhou shibao 欧洲时报, 26 January 2017, http://www.oushinet.com/qj/qjnews/20170126/253568.html (accessed on 23 March 2018).

44. "RAMUNION France," Journal Officiel, 11 March 2017, http://www.journal-officiel.gouv.fr/association $/$ index.php?action=rechercher\&hi_page=1\&hi_compteur=0\&original_method=get\&what =ramunion+\&jth_id=\&jan_bd_cp=\&jre_id=\&jan_lieu_decl=\&jty_id=\&jty_waldec=\&jty_siren=\& jpa_d_d=\&.jpa_d_f=\&rechercher. $x=18 \&$ rechercher. $y=7$ (accessed on 14 March 2018).

45. "RAMUNION France," Annuaire des associations et actualités associatives, 11 March 2017, http://www.net1901.org/association/ramunion-france, 1856952.html (accessed on 14 march 2018).

46. "Ramunion France," Gralon, 11 March 2017, https://www.gralon.net/mairies-france/yvelines/association-ramunion-france-fontenay-le-fleury_W784005297.htm (accessed on 14 March 2018).

47. The single example of the Ram Unions does not allow us to determine whether this approach is part of an overall plan designed to make use of the legislation in force in the countries in which these Ram Unions have been set up, by playing on legal niceties and confusions about notions associated with minjian and NCOS, or whether this is merely an indirect consequence of how these local administrations have normalised these Unions. The only way to settle this would be to undertake many other studies of this kind and develop a general model.

48. Floriane Louison, "Agression d'Aubervilliers: les Chinois disent stop à la violence" (Aubervilliers attack: Chinese say stop to violence), Le Parisien, 17 August 2016, http://www.leparisien.fr/infoparis-ile-de-france-oise/les-chinois-disent-stop-a-la-violence-17-08-2016-6048777.php (accessed on 20 October 2017).

49. “一中国公民与法国警察发生冲突被打死. 驻法大使馆回应” (Yi Zhongguo gongmin yu Faguo jingcha fasheng chongtu bei dasi. Zhu Fa dashiguan huiying, A Chinese citizen was killed by the French police during an altercation. Response of the Chinese Embassy in France), Zhongxinwang 中新网, 27 March 2017, http://www.xinhuanet.com/politics/2017-03/27/__1120705234.htm (accessed on 21 October 2017).

50. Statement by the spokesperson of the French Embassy in Beijing, 28 March 2017, https://cn.ambafrance.org/Declaration-du-porte-parole-28-mars-2017 (accessed on 21 October 2017).

51. The people behind these demonstrations of strength seem to organise them with the aim of assuming the mantle of "protector of the Chinese" within the diaspora. In the context of the heinous attacks against Asians, several small groups would appear to be in competition as they promote their offer of security services. The organisers of the riots seem to want to instrumentalise these violent attacks for commercial purposes in the face of competition.

52. Manon Dognin, "Mort de Shaoyo Liu : les tensions anti-Français s'intensifient en Chine" (The Death of Shaoyo Liu as anti-French tensions in China mount), Marianne, 31 March 2017, https://www.marianne.net/monde/mort-de-shaoyo-liu-les-tensions-anti-francais-s-intensifienten-chine (accessed on 20 October 2017)

53. “巴黎警察总长: 中国公民遭枪杀案涉事警察被停职” (Bali jingcha zongzhang: Zhongguo gongmin zao qiangsha an sheshi jingcha bei tingzhi, The Police Prefect: Chinese citizen shot dead and policeman suspended), Zhongguo giaowang 中国侨网, 29 March 2017, https://www.chinaqw. com/hahr/2017/03-29/133899.shtml (accessed on 21 October 2017). 
body whose aim is to have the diaspora speak with one voice to hammer out the message that Taiwan belongs to China. Since the early 2000s, branches of this body, which is seen as falling under the authority of the UFWD (Zheng 2017), have been set up in all communities of the diaspora.

Several street demonstrations were organised by various collectives. Among the spokespeople for these social movements, however, these two voices were gradually to rise above the others and become the contacts for both the Chinese ${ }^{(54)}$ and French media, ${ }^{(55)}$ to relay the anger of the demonstrators and channel it through to ease the situation. ${ }^{(56)}$ In the Chinese media, they were both clearly presented in their associative function within the diaspora. On the other hand, Franck Bian Haifeng appeared in the French media as a simple businessman coordinating the demonstrations. ${ }^{(57)}$ In Chinese, he was their "organiser," (zhuchi 主持) in the name of Ramunion France, ${ }^{(58)}$ thereby supplanting, together with Wang Jiaqing, all the other community entities. As such, it can be considered that the Ram Union, as a United Front minjian organisation, has completely fulfilled its role as an intermediary body connecting the diaspora, the Prefecture of Police, the media, and the Chinese Embassy. Throughout the crisis, this entity occupied the public arena enough to contain this social movement by giving the necessary signs that it supports it, and to become a privileged interlocutor for the institutions and the media.

Since these events took place, Ramunion France has gone back to its basic roots as organiser of Dragon Boat races ${ }^{(59)}$ that engage the energies of many community associations under the aegis of the Embassy. On the whole it offers a harmonious face, both sporting and apolitical, of the diaspora.

\section{Conclusion}

In the general discussion about redefining the notion of minjian, the Ram Union could be described as a symbiotic organisation, between the Party and society, neither completely minjian, nor completely institutional, even if it is an integral part of the Chinese political and administrative machinery. The feedback from the Taiwanese experience shows that the Rams must, like a number of individuals, act in the face of the relative indifference and inertia of the authorities on the ground. It would clearly seem to be the case that on a day-to-day basis their openly acknowledged activities fall under the heading of popular charity work, sport, and culture, ostensibly far from any state-controlled perspective. Nonetheless, their actions do take place within a very political societal context determined by the Party. In fact, it is a kind of diplomatic avant-garde operating abroad, a showcasing of popular initiatives in very remote and disadvantaged parts of China, and a conveyor belt that can be called upon to go to the front lines whenever a political-social crisis arises. This diversity of para-state functions is possible only by dint of the minjian embedding of the Rams within the social fabric.

Their study thus enables us to expand on Palmer and Ning's analysis of volunteers by considering important United Front issues. The Ram Union embodies a healthy social body in the service of a political mind considered to be healthy as it conforms to the expectations of the Party, in the name of public interest and without having any regular or openly political activity in its day-to-day existence. This positioning helps absorb the diversity of the altruistic, cultural, and festive energies of youth as well as of the middle class. This is in order to fill the social void that could otherwise be taken up by individuals, organisations, or independent networks within which a political alternative might be sprouting. The concept, the fruit of a synergy between the Youth League and the United Front, occupies the social sphere. It enables not only a "preventive mobilisation" (Palmer and Ning forthcom- ing) of society to capture people's energy over the long term, but also a reactive mobilisation of the apparatus to deal with immediate crises.

The Ram Union is thus the example of a kind of a minjian relay structure that is the product of a hybridisation involving various structural aspects of the Party in order to better accompany the social outpourings. According to Palmer and Ning (ibid.), this minjian combined strategy produces a "civil society mobilised" by and for the CCP. This is certainly the ambition of the holistic Party, although not that of the state, since Xi Jinping is strengthening the United Front (Groot 2016) to the detriment of the State Council for anything related to social matters, in particular regarding ethical and religious affairs, and for the diaspora (Smith 2018). This strategy is turning the new humanitarian, social, cultural, and festive minjian into a relay organisation, a medium for symbiosis between the CCP and society. It contributes to the construction of the nation-Party as heir to the revolutionary volunteer spirit, which is supplanting the nation-state and which, whilst being underwritten by the former, is far from the revolutionary spirit. In China, this approach allows the CCP to bypass the state's regulations that it stipulates and of which it is guarantor (the right of association, of belief, etc.) in order to head off or appropriate the possible aspirations of society that, piece by piece, it wants to dominate, embody, and guide, both institutionally and ideologically. Abroad, it authorises the Party to project this ambition onto the diaspora, whatever the nationality of those concerned, ${ }^{(60)}$ henceforth working on its "minjianisation" through an "NCO-ing" of its set-up, by making use of the local rules on freedom of association in civil society.

54. “呼唤正义旅法华人追悼刘少尧” (Huhuan zhengyi Lüfa huaren zhuidao Liu Shaoyao, Demand for justice, the Chinese of France pay homage to Liu Shaoyao), Ouzhou shibao 欧洲时报, 3 April 2017, http://www.oushinet.com/wap/qj/qjnews/20170403/259414.html (accessed on 20 October 2017); “旅法华人聚集巴黎共和国广场维权呼唤正义” (LüFa huaren juji Bali gongheguo guangchang weiquan huhuan zhengyi, Rally by the Chinese of France at the Place de la République, they demand the right to justice), Ouzhou shibao 欧洲时报, 3 April 2017, http://www. oushinet.com/wap/qj/qjnews/20170403/259419.html (accessed on 23 October 2017)

55. "Mort de Shaoyo Liu: la communauté chinoise manifeste à Paris" (The death of Liu Shaoyao: the mobilisation of the Chinese diaspora eases), France TV info, 3 April 2017, http://www.francetv info.fr/faits-divers/mort-de-liu-shaoyo/mort-de-shaoyo-liu-la-communaute-chinoise-manifestea-paris_2126805.html (accessed on 20 October 2017).

56. Thibault Harold and Vincent Elise, "Mort de Liu Shaoyao: la mobilisation de la diaspora chinoise s'apaise" (The death of Liu Shaoyao: the mobilisation of the Chinese diaspora eases), Le Monde, 1 April 2017, http://www.lemonde.fr/police-justice/article/2017/04/01/mort-de-liu-shaoyao-lamobilisation-de-la-diaspora-chinoise-s-apaise_5104286_1653578.html (accessed on 20 October 2017).

57. "Mort de Shaoyo Liu: la communauté chinoise manifeste à Paris" (The death of Shaoyo Liu: the Chinese community demonstrates in Paris), France TV info, 3 April 2017, http://www.france tvinfo.fr/faits-divers/mort-de-liu-shaoyo/mort-de-shaoyo-liu-la-communaute-chinoise-manifeste-a-paris_2126805.html (accessed on 21 October 2017).

58. “旅法华人聚集巴黎共和国广场维权呼唤正义” (LüFa huaren juji Bali gongheguo guangchang Weiquan huhuan zhengyi, Place de la République rally by Chinese living in France demanding the right to justice), Ouzhou shibao 欧洲时报, 3 April 2017, http://www.oushinet.com/wap/ qj/qjnews/20170403/259419.html (accessed on 20 October 2017).

59. “法国公羊会全力备战法国侨界龙舟大赛” (Faguo Gongyanghui quanli beizhan Faguo qiaojie longchuan dasai, The Ram Union of France actively prepares the Dragon Boat race of the Chinese diaspora in France), 14 June 2017, http://dy.163.com/v2/article/detail/CMSCAJC60514BIH4.html (accessed 29 November 2017); “法国首届公羊会龙舟赛” (Faguo shouxian Gongyanghui longchuan sai, First Dragon Boat race of the Ram Union of France), 1 July 2017, https://www.youtube.com/watch?v=9a693rd9JLM (accessed on 11 March 2018); “法华代表队 将参加“穿越塞纳”花样划船赛 展现华人风采” (Faguo daibiaodui jiang canjia "chuanyue Saina" huayang huachuan sai zhanxian huaren fengcai, The team of the Chinese of France states its intention to take part in the "La TraverSeine" to show the Chinese style of rowing), Ouzhou shibao 欧洲时报, 11 August 2017, http://www.oushinet.com/wap/qj/qjnews/20170811/269243.html (accessed on 11 March 2018); “法国公羊会在新春晚会上宣布: '今年将继续举办龙舟赛”' (Faguo Gongyanghui zai xinchun wanhui xuanbu: jinnian jiang jixu banju longzhou sai, During the New Year celebrations, the Ram Union of France made the following announcement: "This year we will continue to organise the Dragon Boat races"), Ouzhou shibao 欧洲时报, 6 February 2018, http://www.oushinet.com/qj/qjnews/20180206/283826.html (accessed on 11 March 2018).

60. China does not recognise dual nationality, and many members of the Chinese diaspora are nationals of their country of residence. 
Detecting, understanding, and apprehending this implementation and its consequences is complex. The question of Overseas Chinese is not new for the CCP or the KMT. As long as it was a matter of catching, politically, offshoots of structures like those connected with the reunification of China, the approach remained as easy as it was heavy-handed. Things changed, however, as soon as the relay structures were created ex-nihilo or reformatted in China to take on minjian attributes, and they presented themselves overseas as NGOs with the avowed objective having nothing to do with politics. Research on the redefinition of the concept of minjian in China by reference to the Western notion of civil society needs to take into account the way in which the PRC projects it

\section{References}

ARMSTRONG, J.D. 1977. Revolutionary Diplomacy, Chinese Foreign Policy and the United Front Doctrine. Berkeley, Los Angeles, and London: University of California Press.

AUDIN, Judith. 2013. Vie quotidienne et pouvoir dans trois quartiers de Pékin: une microsociologie politique comparée des modes de gouvernement urbain au début du $21^{e}$ siècle (Daily life and power in three Beijing neighbourhoods). Doctoral dissertation: Political Science: Paris: Institut d'Études Politiques.

BILLIOUD, Sébastien. 2007. "Confucianism, 'cultural tradition' and official discourses in China at the start of the new century." China Perspectives 3(100): 50-65.

BILLIOUD, Sébastien, and Joël THORAVAL. 2014. Le Sage et le peuple, Le renouveau confucéen en Chine (The sage and the People). Paris: CNRS Éditions.

BILLIOUD, Sébastien, and Joël THORAVAL. 2009. "La Chine des années 2000: regards nouveaux sur le politique" (China in the years 2000). Extrême-Orient Extrême-Occident (1): 5-31.

CHEN, Jiagang 陈家刚. 2017. “基层协商民主的实践路径与前景” (Jiceng xieshang minzhu de shijian lujing yu qianjing, The practical path and prospect of primary-level consultation democracy). Zhongguo Zhengzhi 中国政治 (10).

CHONG, Gladys Pak Lei. 2011. "Volunteers as the 'new' model citizens: Governing citizens through soft power." China Information 25(1): 33-59.

DOYON, Jérôme. 2017. Rejuvenating Communism, The Communist Youth League as a Political Promotion Channel in Post-Mao China. Doctoral dissertation in Political Science: Paris: Columbia University/Sciences Po Paris.

GROOT, Gerry. 2016. "The Expansion of the United Front Under Xi Jinping." In Gloria Davies, Jeremy Goldkorn, and Luigi Tomba (eds.), China Story Yearbook 2015. Pollution. Canberra: ANU Press. 168-77.

HOLBIG, Heike. 2009. "Remaking the CCP's Ideology: Determinants, Progress, and Limits under Hu Jintao." Journal of Current Chinese Affairs 3(38): 35-61.

HOMER, Lauren B. 2010. "Registration of Chinese Protestant House Churches under China's 2005 Regulation on Religious Affairs: Resolving the Implementation Impasse." Journal of Church and State 1(52): 50-73.

HSU, Jennifer Y.J., and Hasmath REZA (eds.). 2013. The Chinese Corporatist State: Adaption, Survival and Resistance. New York: Routledge.

JIANG, Qing. 2003. Political Confucianism. Beijing: The Jointly Press. onto the diaspora, which has become an integral part of civil society in the host countries.

I Translated by Peter Brown.

I Emmanuel Jourda has a PhD in Political Science at the CECMC of the EHESS (École des Hautes Études en Sciences Sociales). His thesis deals with the post-revolutionary form of the Chinese regime, particularly the way in which it restructures itself through United Front policies (ejourda@aol.com).

Article received on 11 September 2018. Accepted on 8 April 2019.

JOURDA, Emmanuel. 2012. Les usages postrévolutionnaires d'un canon orthodoxe: le Front Uni et l'invention politique de l'après-révolution en Chine (1978-2008) (The post-revolutionary uses of an orthodox institution). Doctoral dissertation in Political Science. Paris: EHESS.

PALMER, David A., and Rundong NING. Forthcoming. "The resurrection of Lei Feng: Rebuilding the Chinese Party-state's infrastructure of volunteer mobilization." In Elizabeth Perry, Grzegorz Ekiert and Xiaojun Yan (eds.), Ruling by Other Means: State-Mobilized Social Movements. Cambridge: Cambridge University Press.

QI, Weiping 齐卫平. 2011. “包容: 新阶段人民政协的工作特点” (Baorong: xin jieduan renmin zhengxie de gongzuo tedian, Tolerance: The feature of the work of People's Political Consultative Conference in the new stage). Zhongguo zhengzhi 中国政治 (3).

SAICH, Tony. 2000. "Negotiating the State:The Development of Social Organizations in China." The China Quarterly 161(March): 124-41.

SCHURMANN, Franz. 1968. Ideology and Organization in Communist China. Berkeley and Los Angeles: University of California Press.

SMITH, Graeme. 2018. "Xi Jinping Gives China's United Front a Bureaucratic Boost." War on the Rocks, 1 May 2018. https://warontherocks.com/ 2018/05/xi-jinping-gives-chinas-united-front-a-bureaucratic-boost/ (accessed on 5 June 2018).

WANG, Wenzhang 王文章. 2012、“现代化视野下的我国公民社会发展路径 探析" (Xiandaihua shiye xia de woguo gongmin shehui fazhan lujing tanxi, The pathway of the development of China's citizen society under the view of modernisation). Zhongguo zhengzhi 中国政治 (1).

YANG，Weimin 杨卫敏. 2015. “基层协商民主应是我国协商民主建设的重 中之重" (Jiceng xieshang minzhu yingshi woguo xieshang minzhu jianshe de zhongzhong zhi zhong, Consultative democracy at the primary level is the first priority in the consultative democracy construction of China). Zhongguo Zhengzhi 中国政治 (3).

YAO, Yuan 姚远, and REN Yuzhong 任羽中. 2013. “激活”与'吸纳”的互动一 走向协商民主的中国社会治理模式" ("Jihuo" yu "xina" de hudong - zouxiang xieshang minzhu de Zhongguo shehui zhili moshi, The Interaction between "activation" and "absorption": A model of social governance in China as an enactment of deliberative democracy), Zhongguo zhengzhi 中国政治 (6).

ZHENG, Zhang. 2017. "What Is the CCPPNR and the UFWD?" Vision Times Special Edition. https://www.visiontimes.com.au/pdf/22.pdf (accessed on 5 June 2018). 
ZHONG, Xiangting 钟想廷 (ed.). 2001. 街道社区党建工作 - 手册 (Jiedao shequ dangjian gongzuo - shouce, The foundational work of the Party in the streets and communities, manual). Taiyuan: Shanxi renmin chubanshe 山西人民出版社.

ZHU, Guanglei 朱光否, and YU Dan 于丹. 2015. “论对政治行为的'社会化处 理"' (Lun dui zhengzhi xingwei de "shehuihua chuli," The socialised promotion for political actions). Zhongguo Zhengzhi 中国政治 (4).
ZHU, Shuyue 祝淑月. 2009. “民主党派参与公共政策制定的实践分析一以 近十年民主党派浙江省委会提交的提案为分析对象” (Minzhu dangpai canyu gonggong zhengce zhiding de shixian fenxi - Yi jin shinian minzhu dangpai Zhejiangsheng weiyuanhui tijiao de ti'an wei fenxi duixiang, Analysis on democratic parties' participating in the practice of public policy: Based on the proposal submitted by democratic parties in Zhejiang Province in the last ten years). Zhongguo zhenghi 中国政治 (7). 